\title{
Digital Gap in EU Countries and its Impact on Labour Productivity and Global Competitiveness
}

\author{
Tetiana POLOZOVA ${ }^{1}$, Irina KOLUPAIEVA ${ }^{2 *}$ and Iryna SHEIKO ${ }^{3}$ \\ Kharkiv National University of Radio Electronics, Kharkiv, Ukraine; tetiana.polozova@nure.ua; \\ iryna.kolupaieva@nure.ua; irina.sheiko@nure.ua \\ * Corresponding author: iryna.kolupaieva@nure.ua
}

\begin{abstract}
Nowadays digitalization has become a global trend that allows countries and individuals to get a number of benefits for economic and social development. Every country is trying to promote digital innovation through regulatory policies. However, the results of such policies vary for different countries, creating digitalization gaps. The aim of the research is to assess the gaps in digitalization process and productivity among EU-members countries, and to evaluate how such gap impact on competitiveness of the country. On the basis of DESI index and labour productivity data for EU-members four clusters were formed. Also, on the base of International DESI index and Global Competitiveness Score EU-members and seven global developed countries were divided into four clusters. As a result, leaders, perspective countries, followers and transition countries were identified reflecting the digital and labour productivity divide between them. Leading positions are occupied by North Europe countries, while number of Eastern Europe countries located at opposite side. Results of cluster analysis shows the linkage between digital development and human development due to co-movement of DESI and Human Development Index.
\end{abstract}

Keywords: digitalization; labour productivity; competitiveness; k-means clustering; Information Development Index; Human Development Index

JEL Classification: C38; O57; P51

\section{Introduction}

All countries at global level provided actions to improve their digital development. Although digitalization is spreading globally, there are global and regional leaders in ICT and digital development, that can be proved by different global rankings. Existing gaps motivate developing countries to bridge the global economic disparities caused by technological and digital gaps (Bilozubenko et al., 2020). On this reason analysis and comparing of digital economy parameters of different countries is actual, especially if countries represent the same region or join together like European Union. The digital division between countries can also be assessed at the individual level, covering the use of ICT by the population and business (Chipeva et al., 2018), as well as at the household level (Lucendo-Monedero et al., 2019), which is necessary for understanding the sources, landscape and magnitude of differences. 
Milošević et al. (2018) created a multivariate Composite I-distance Indicator (CIDI) to measure digital economy performance. They found, that Denmark tops the ranking list, followed by Sweden and Netherlands, lowest ranked countries are Romania and Bulgaria.

Androniceanu et al. (2019) divide EU countries on five clusters with leading Nordic countries and Romania and Bulgaria outsiders. Authors collected 10 indicators from Eurostat's Digital Economy and Society database.

Mardikyan et al. (2015) investigated disparities between groups of countries (continents) in terms of ICT accessing and using at global level. They found significant difference in digital activity between developed and developing countries and between OECD member and not member countries.

Bilozubenko et al. (2020) defined five key indexes of digital development, and then on the base of such indexes EU countries were divided into three clusters: leaders, followers and outsiders.

Foster and Azmeh (2020) investigated national digital policies, with a focus on China, they proved that these policies often aim at facilitating global integration and linkages. Author's analysis shows that more interventionist approaches can be vital in countering structural challenges, such as power of digital platforms, limitations of domestic digital firms, limited ability to leverage digitalization for broad-based national development.

Van Ark et al. (2003) provides an analysis of the trends in labour productivity and employment growth at EU and USA during the 1990s. The main findings are that the inverse relationship between employment and productivity growth has been much more prominent in manufacturing industries than in services industries. The employmentreducing effects of productivity growth have remained considerably stronger in Europe than in the USA.

Biagi (2013) provides literature review concerning ICT and productivity. The author concludes that ICT had a major role in the U.S. productivity acceleration observed in the period 1995-2005. Sweden and Finland took full advantage of the opportunities offered by digital technologies, while others, such as Germany, France and Italy to a lesser extent, the UK, did not. Biagi also pointed out, that ICT is largely responsible for the divergence in productivity paths observed between 1995 and 2005 for the U.S. and the E.U. (Biagi, 2013). Also, author found large variation in the impact of ICT on productivity within the EU members.

A lot of indexes evaluate digital development all over the world. The Digital Economy and Society Index (DESI) is an integrated index that summarizes dimensions and estimates digital competitiveness. The DESI index includes 5 main areas: connectivity, human capital, use of internet services, integration of digital technology, digital public services (DESI, 2020).

The International Digital Economy and Society Index (I-DESI) mirrors and extends the EU28 Digital Economy and Society Index (DESI) by utilizing 24 datasets to enable trend analysis and comparison of the digital performance of 45 countries. Analysis showed that EU28 Member States compare well with 17 non-EU countries and top EU28 countries have digital performances at the same or higher levels than the best global competitors. Indeed, 
Denmark was the leading country in the I-DESI index. EU28 Member States perform best, relative to the 17 non-EU countries, in the Connectivity dimension (examining the deployment and take-up of fixed and mobile broadband) and in the Citizen Use of the Internet dimension.

Significant studies dedicate the issues of impact of digitalization development on progress in global rankings of the country: Information development Index, Global competitiveness ranking, Human development Index.

A lot of researches also connects the development of human capital, parameters of labour market with digital progress (Amuso et al., 2019; Ark Van et al., 2003; Nambisan et al., 2019; Polozova, 2015; Terziyan, 2018). It will be useful to investigate the effect of digitalization process in EU-members on their progress in global rankings, such as Global Competitiveness Ranking (WEF, 2018), Human development ranking (UND, 2018), Information development Index (IDI, 2018).

The purpose of the paper is to assess the gaps in digitalization process and productivity among EU-members countries, and to evaluate how does such gap impact on competitiveness of the country.

\section{Methodology}

To define the digital gaps within EU-members such methods as cluster analysis and classification were used. Such methods allow to identify important patterns, to determine causality. The difference among such methods lies in the fact that classification uses predefined clusters in which objects are assigned, while clustering identifies same characteristics between objects and then group of similar objects form cluster. Classification needs to define main factors to provide division on clusters.

There are a lot of parameters that are used to describe digital economy performance. Thus, the basis for clustering is a feature description of objects. Object $X$ (digital economy of EU-member) consists a set $X=(x 1, x 2, \ldots, x n)$ of discrete values of attributes (a discrete set of $X)$.

To provide cluster analysis at first, we have to define the key factors for division of EUmembers. In works (Androniceanu et al., 2019; Bilozubenko et al., 2020; Balcerzak \& Pietrzak, 2017) the key classification factors were aspects of digitalization process. But the issues of economic effects of digitalization process need to be investigated deeply.

Scientists pay a lot of attention to the impact of information technology and digitalization on productivity. OECD report (OECD, 2016) proposes the process (figure 1) through which ICT investments are complemented with investments in knowledge-based capital (KBC) to support digital innovation, which in turn improves business effectiveness (e.g. higher productivity, profitability, and market share) and leads to higher aggregate productivity growth. On the basis of such scheme we can use labour productivity as one of the key factors to provide cluster analysis. Together with digitalization index productivity allows us to divide EU-members not only on digital clusters, but also on productivity. 


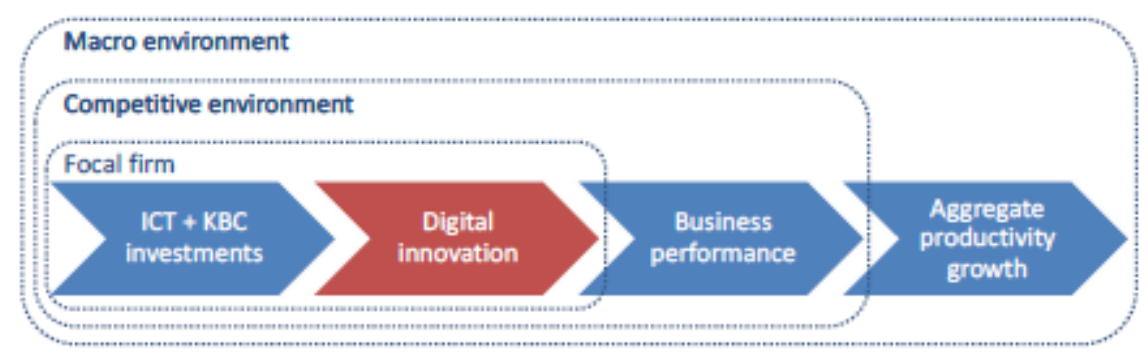

Figure 1. From ICT investments to aggregate productivity growth. Source: OECD, 2016

Another important step is of our study is comparing EU-members with group of global developed countries. We propose to provide cluster analysis on the basis of DESI International index with Global Competitiveness Score. Such cluster division will show gaps in economic and competitiveness effects on digital processes for EU countries and global competitors.

In our research we use DESI and DESI International Indexes.

Figure 2 presents correlation between digitalization indexes (DESI and DESI International) and Labour productivity (a), Global Competitiveness Score.

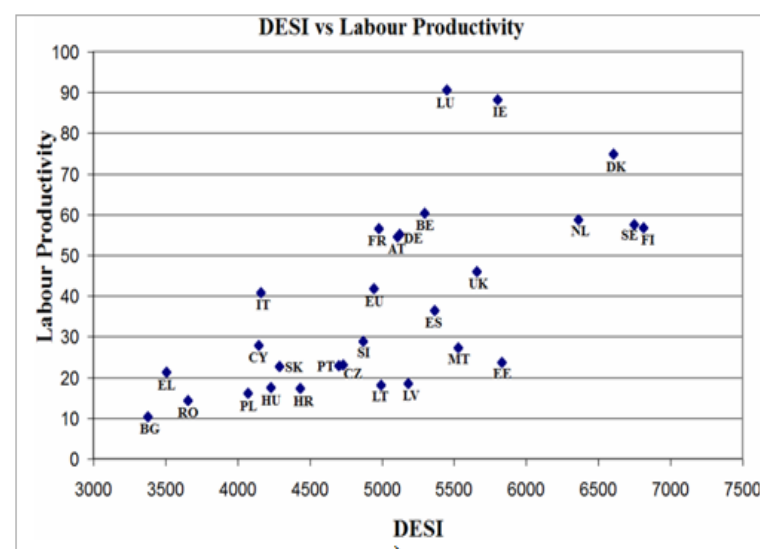

a)

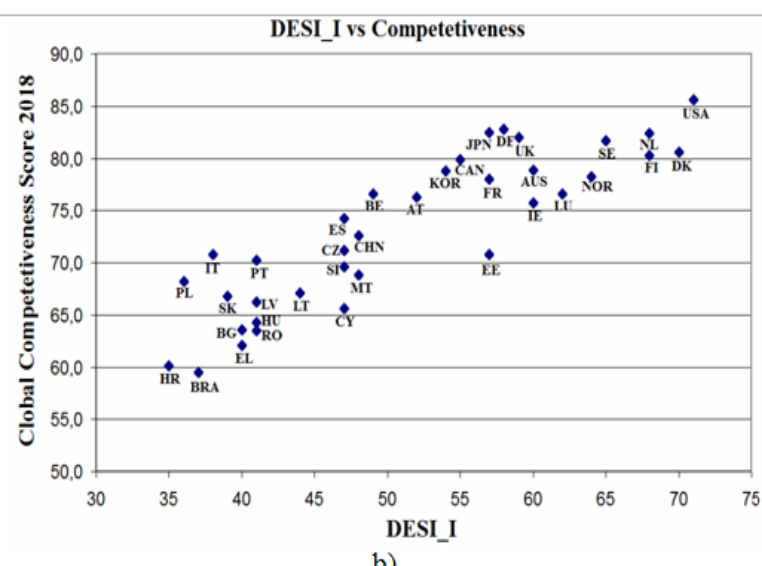

b)

Figure 2. Correlation between DESI Indexes and Labour productivity (a), Global Competitiveness Score (b).

The correlation between factors is rather strong: between DESI and labour productivity 0.67; between DESI International and Global Competitiveness Score 0.84. Authors (Abonyi $\&$ Feil, 2007) proved that if initial data for cluster analysis are correlated, hyperellipsoidal clusters can be effectively used to represent correlated data, and local linear models can be easily extracted from the parameters of these clusters.

Data that we used in our research consists:

1. DESI 2019 Index with labour productivity Euro per hour (Eurostat, 2019). On the base of this data we expect to determine digital-productivity clusters for EU-members.

2. DESI International Index 2018 with Global Competitiveness Ranking Score (WEF, 2018). To compare digital performance of EU-members we add data of eight high developed countries: USA, China, Korea Rep., Japan, Australia, Canada, Norway and Brazil, that represent different regions. Clusters will be made on the basis of Global Competitiveness rating score (WEF, 2018). 
3. Information development Index (IDI, 2018), Human development index (HDI, 2018). We need these indexes to check co-movement in digital development and progress in IT sector and human development

Descriptive statistics of variables is shown in Table 1.

Table 1. Description of variables and descriptive statistics

\begin{tabular}{|l|l|c|r|r|r|r|}
\hline $\begin{array}{l}\text { Name of } \\
\text { variable }\end{array}$ & Description & $\begin{array}{l}\text { Valid } \\
\text { cases }\end{array}$ & Mean & Min & Max & STD \\
\hline DESI & Digital Economy and Society Index (DESI) & 29 & $4,636.2$ & $2,613.29$ & 7,231 & $1,001.9$ \\
\hline DESI_CON & Dimension of Connectivity of DESI & 29 & $4,685.6$ & $2,726.51$ & 7,844 & $1,171.6$ \\
\hline DESI_HC & Dimension of Human Capital of DESI & 29 & $4,132.9$ & $1,744.39$ & 6,582 & 984.2 \\
\hline DESI_U & Dimension of Use of Internet Service of DESI & 29 & $4,567.2$ & $2,170.69$ & $7,634.1$ & $1,184.2$ \\
\hline DESI_IDT & $\begin{array}{l}\text { Dimension of Integration of Digital technology } \\
\text { of DESI }\end{array}$ & 29 & $3,737.9$ & $1,528.36$ & 7,432 & $1,290.3$ \\
\hline DESI_PUB & Dimension of Digital Public Service of DESI & 29 & $6,108.9$ & $2,062.14$ & 8,933 & $1,508.9$ \\
\hline L_PR_H & Real labour productivity in hour, Euro & 29 & 38.93 & 10.40 & 90.70 & 22.50 \\
\hline DESI_I & $\begin{array}{l}\text { International Digital Economy and Society } \\
\text { International Index (DESI_I) }\end{array}$ & 36 & 51.19 & 35.0 & 71.0 & 10.69 \\
\hline CON & Dimension of Connectivity of DESI_I & 36 & 62.06 & 46.0 & 74.0 & 6.15 \\
\hline SKILLS & Dimension of Human Capital of DESI_I & 36 & 42.81 & 24.0 & 66.0 & 11.16 \\
\hline USE & Dimension of Use of Internet Service of DESI_I & 36 & 49.58 & 27.0 & 74.0 & 11.91 \\
\hline IDT & $\begin{array}{l}\text { Dimension of Integration of Digital technology } \\
\text { of DESI_I }\end{array}$ & 36 & 42.83 & 10.0 & 83.0 & 20.89 \\
\hline PUB & Dimension of Digital Public Service of DESI_I & 36 & 59.61 & 26.0 & 86.0 & 15.29 \\
\hline COMP & Global Competitiveness rating score & 36 & 73.11 & 59.5 & 85.6 & 7.33 \\
\hline
\end{tabular}

Given the specifics of the data set, for the country clusterization, a k-means algorithm is used (Abonyi \& Feil, 2007). The k-means algorithm uses the unscaled squared Euclidean distances for the distance measure.

To provide cluster analysis we have used Statistica software, the method of k-means clustering ( $\mathrm{k}$ is the number of clusters). The program starts with $\mathrm{k}$ random clusters, and then move objects between those clusters with the goal to minimize variability within clusters and to maximize variability between clusters. Thus, $\mathrm{k}$ distinctive clusters are formed. In $k$-means clustering, the program tries to move objects (e.g., cases) in and out of groups (clusters) to get the most significant results.

Presented analysis, grounded on theoretical framework, leads to determine main research hypotheses:

H1: there is a significant gap within EU-members in digital development and labour productivity

H2: digital development of EU-members can improve country's global rankings: Global Competitiveness Score, Information development Index, Human development index.

These hypotheses should be checked in the research.

\section{Results}

\subsection{Digitalization and Labour Productivity}

To divide EU_members countries on several groups in accordance of digital development and labour productivity level cluster analysis was used. 
Usually, as the result of a k-means clustering analysis, we would examine the means for each cluster on each dimension to assess how distinct our k clusters are. Ideally, we would obtain very different means for most, if not all, dimensions used in the analysis. The magnitude of the $\mathrm{F}$ values from the analysis of variance performed on each dimension is another indication of how well the respective dimension discriminates between clusters.

Cluster analysis shows, that there is significant gap between EU-members in digital performance and in labour productivity. The correlation between these two parameters is positive cases: higher digitalization index has higher level of productivity.

Clusters are represented in 2-dimension scale at figure (Figure 3, Figure 4). The form of clusters is chosen to cover all cases. The center of each cluster is marked by dot; also, the nearest case (country with minimal diagonal distance from respective cluster center) is marked.

Due to results of cluster analysis four clusters were formed:

- leading cluster includes 4 countries: Denmark, Finland, Sweden and Netherlands;

- perspective cluster includes 7 countries: Luxembourg, Ireland, UK, Belgium, Spain, Malta and Estonia;

- follower cluster consists 9 countries: France, Austria, Germany, EU (average level), Slovenia, Czech Republic, Lithuania, Latvia, Portugal;

- transiting cluster represents 9 countries: Italy, Slovakia, Cyprus, Croatia, Hungary, Poland, Romania, Greece and Bulgaria.

Even that the same countries, specifically, Romania and Bulgaria place in a lower position compared to other European countries by all digitalization indicators, these countries also offer the greatest potential. Recent McKinsey report (Novak et al., 2018) discusses how digitization can accelerate economic development of Eastern and Central European countries. Authors found, that region has a great potential in digitalization, including high human development and education level, high level of infrastructure, great industrial capabilities. But authors also pointed out important challengers: brain drain of young IT specialists, intellectual-property protection, absence of basic digital skills for large part of population.

Due to results of cluster analysis we can find countries, which allocated too far from cluster centers. Transiting and leading clusters are most concentrated. In leaders maximum Euclidian distance from the mean has Netherlands, in transiting cluster - Bulgaria. In perspective cluster countries that have maximum distances from respective cluster center are Ireland, Estonia and Belgium. In followers cluster such "remote" countries are Portugal and Lithuania.

Results of DESI-labour productivity division shows the main problem of clustering the difference in scale between DESI Index and labour productivity. Due to small variation of productivity within each cluster the main role of referring each case (country) to definite cluster belongs to DESI Index.

Results of DESI-labour productivity shows an existence of digital gaps within EU. 


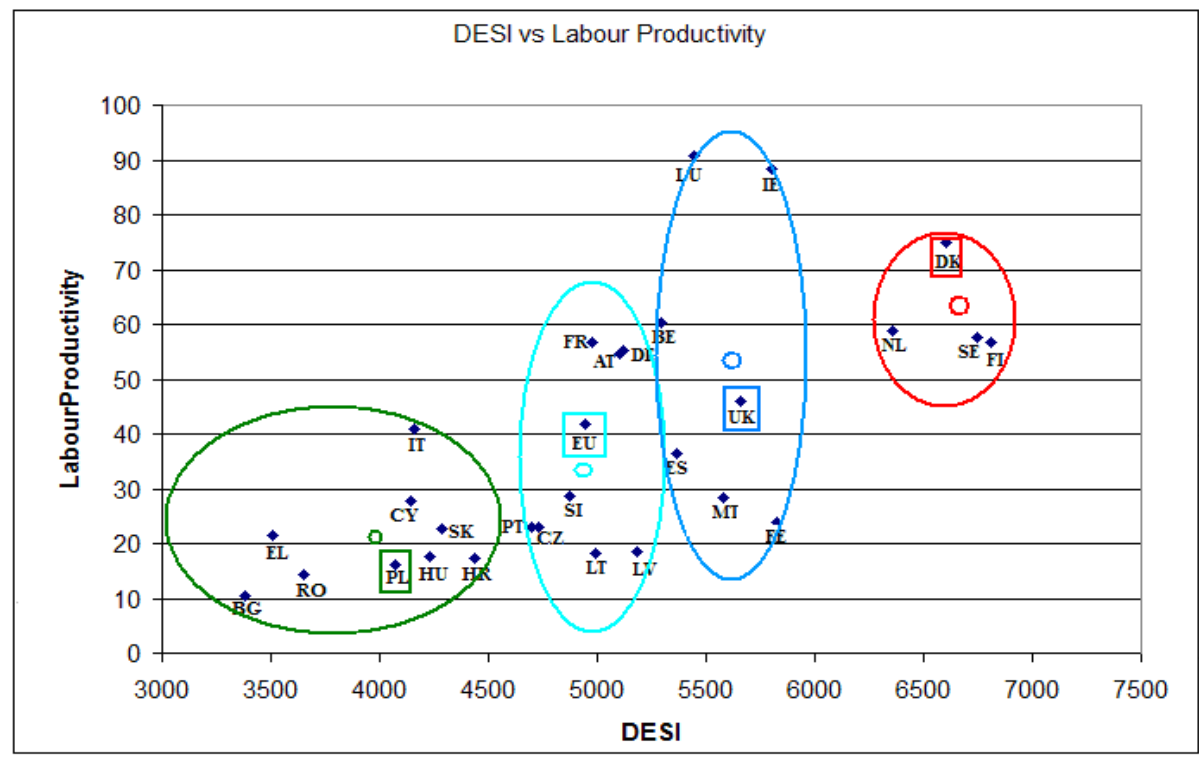

\footnotetext{
- mean (center) of cluster;
}

Abbreviation used: EU-European Union, AU -Austria, BE- Belgium, BG- Bulgaria, HR - Croatia, CY Republic of Cyprus, CZ - Czech Republic, DK - Denmark, EE-Estonia, FI-Finland, FR-France, DE-Germany, EL Greece, HU-Hungary, IE-Ireland, IT-Italy, LV-Latvia, LT-Lithuania, LU-Luxembourg, MT-Malta, NLNetherlands, PL-Poland, PT-Portugal, RO-Romania, SK-Slovakia, SI-Slovenia, ES-Spain, SE-Sweden, UK- United Kingdom

Figure 3. Results of cluster analysis DESI-Labour productivity for EU-members

\subsection{Digitalization and Global Competitiveness}

The next step of investigation is analyzing how digital development can support global competitiveness. So that, we make cluster analysis on two parameters: international DESI index (DESI_I) and Global Competitiveness Rating 2018 Score (WEF, 2018).

We define the same numbers of clusters 4 and provide clustering of EU countries with developed countries from different regions: USA, China, Japan, Korea, Canada, Australia, Norway and Brazil. Now DESI International Index and Global Competitiveness Score have the same scale, that make cluster analysis easier. As a result, we receive more concentrated clusters (Figure 4).

Due to cluster analysis we can make some conclusions.

Leaders save their positions in leading cluster: USA and Norway join Denmark, Finland, Sweden and Netherlands.

Most of countries in transiting cluster also remain their positions: with the exception of Cyprus, that goes up to followers cluster and Latvia goes down to transition from followers. Brazil also appears in transition cluster.

High score at global competitiveness ranking allows UK, Luxembourg, Ireland to improve positions in perspective cluster and to Austria, France and Germany to move up to this cluster. Canada, Japan, Korea, Australia appear at perspective cluster.

Belgium, Malta and Spain go down to follower cluster.

Most of non-EU countries belong to leading and perspective clusters. 


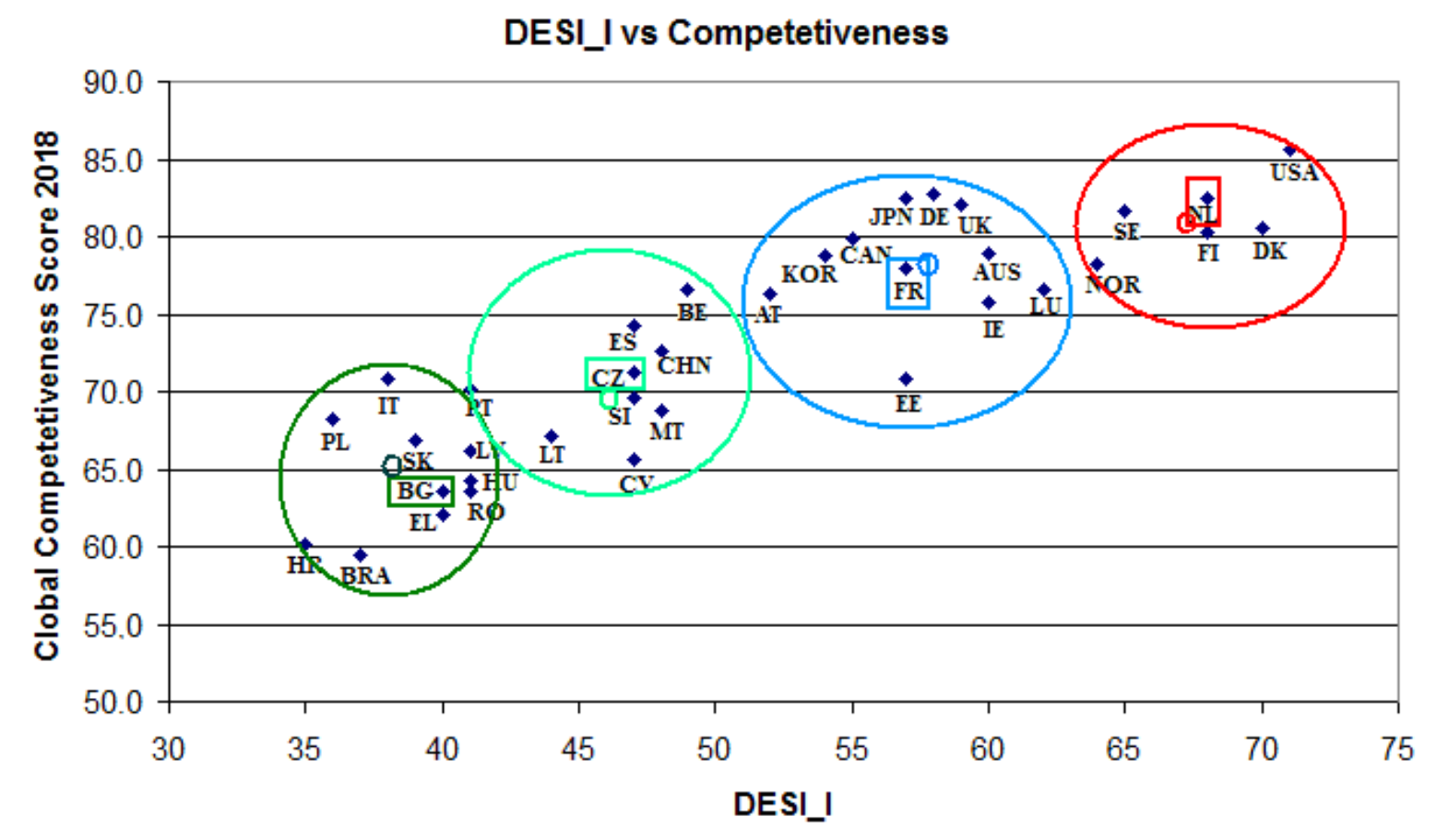

- mean (center) of cluster;

Abbreviation used for Non-EU Countries: AUS -Australia, BRA-Brazil, CAN-Canada, CHN-China, JPNJapan, KOR- Rep. of Korea, NOR-Norway, USA

Figure 4. Results of DESI_I_-Global Competitiveness Score cluster analysis for EU members and global developed countries. Source: constructed by authors

\subsection{Summary Grouping of EU Members}

In Table 2 countries are grouping according four DESI-productivity clusters (Figure 3). Also, to compare the progress of each country in global competitiveness ranking the clustering results of DESI_I with Global Competitiveness Score are shown (Figure 4).

Due to represented data, we can make a conclusion, that most of EU-members remain the same digitalization cluster for DESI-productivity cluster analysis and DESI International - Global Competitiveness Ranking 2018 Score.

So, European countries are competitive at global digital market, and such digital development improves their positions in Global Competitiveness Ranking. Also we can conclude that members of leading cluster have higher positions in IDI and HDI Rankings, then countries of transition cluster. Of course, ICT development and digital development has a lot of same parameters that is why higher digital developed country has higher positions in IDI ranking. UK, Germany and Ireland in HDI and IDI Ranking does not correspond the general tendency - they have higher positions in IDI ranking, but not belong to leading cluster.

But digital development is one of the many factors that determine ICT and human development. That is why the co-movement of such ranking is not proved and needs further investigations. 
Table 2. Values of Global Competitiveness Ranking, ICT development Index and Human development Index for EU countries with the distribution by clusters

\begin{tabular}{|c|c|c|c|c|}
\hline $\begin{array}{l}\text { EU member } \\
\text { due to DESI- } \\
\text { productivity } \\
\text { clusters }\end{array}$ & $\begin{array}{l}\text { Cluster in DESI_I } \\
\text { global rating } \\
\text { (DESI_I vs Global } \\
\text { Competitiveness } \\
\text { Ranking } 2019 \text { Score) }\end{array}$ & $\begin{array}{l}\text { Global } \\
\text { Competitiveness } \\
\text { Ranking } 2019 \text { Score }\end{array}$ & $\begin{array}{l}\text { Position in } 2019 \\
\text { ICT development } \\
\text { Index (IDI) }\end{array}$ & $\begin{array}{l}\text { Position in } 2019 \\
\text { Human } \\
\text { development Index } \\
\text { (HDI) }\end{array}$ \\
\hline \multicolumn{5}{|c|}{ Leading cluster } \\
\hline Denmark & leading & 80.6 & 4 & 11 \\
\hline Finland & leading & 80.3 & 22 & 15 \\
\hline Sweden & leading & 81.7 & 11 & 7 \\
\hline Netherlands & leading & 82.4 & 7 & 10 \\
\hline \multicolumn{5}{|c|}{ Perspective cluster } \\
\hline UK & perspective & 82.0 & 5 & 14 \\
\hline Ireland & perspective & 75.7 & 20 & 4 \\
\hline Malta & follower & 68.8 & 24 & 29 \\
\hline Estonia & perspective & 70.8 & 17 & 30 \\
\hline Belgium & follower & 76.6 & 25 & 17 \\
\hline Luxembourg & perspective & 76.6 & 9 & 21 \\
\hline Spain & follower & 74.2 & 27 & 26 \\
\hline \multicolumn{5}{|c|}{ Follower cluster } \\
\hline EU & - & - & - & - \\
\hline Germany & perspective & 82.8 & 12 & 5 \\
\hline Austria & perspective & 76.3 & 21 & 20 \\
\hline Czechia & follower & 71.2 & 43 & 27 \\
\hline Lithuania & follower & 67.1 & 41 & 35 \\
\hline France & perspective & 78.0 & 15 & 24 \\
\hline Slovenia & follower & 69.6 & 33 & 25 \\
\hline Portugal & follower & 70.2 & 44 & 41 \\
\hline Latvia & transiting & 66.2 & 35 & 41 \\
\hline \multicolumn{5}{|c|}{ Transiting cluster } \\
\hline Croatia & transiting & 60.1 & 36 & 46 \\
\hline Hungary & transiting & 64.3 & 48 & 45 \\
\hline Slovakia & transiting & 66.8 & 46 & 38 \\
\hline Poland & transiting & 68.2 & 49 & 33 \\
\hline Cyprus & transiting & 65.6 & 28 & 32 \\
\hline Italy & transiting & 70.8 & 47 & 28 \\
\hline Romania & transiting & 63.5 & 58 & 52 \\
\hline Greece & transiting & 62.1 & 38 & 31 \\
\hline Bulgaria & transiting & 63.6 & 50 & 51 \\
\hline
\end{tabular}

\section{Discussion}

Based on the proposed feature description and clustering methods, the EU countries were divided into four clusters according to the level of digital development and labour productivity. As a result, leaders, perspective countries, followers and transition countries were identified reflecting the digital and labour productivity division between them. Leading positions are occupied by North Europe countries, that correspond with other researches (Bilozubenko et al., 2020; Androniceanu et al., 2017, 2019; Chakravorti \& Chaturvedi, 2017; Chipeva et al., 2018; Lucendo-Monedero et al., 2019). Two intermediate clusters - perspectives and followers consists 16 countries. Luxembourg and Ireland characterized with highest level of labour productivity, and they don't win leading 
positions in digital development. That is why they appears in perspective cluster. Also, EUmembers were compared with global developed countries depending on DESI international Index and score in Global Competitiveness ranking. The results of clusterization show that leaders and transition countries save their position, but intermediate clusters consist of some changes.

Results of cluster analysis show the linkage between digital development and human development due to co-movement of DESI and Human Development Index.

As the results of our investigation we can prove the correctness of our first hypothesis and partially proved second hypothesis (Table 4).

But our research did not reach significant results with regard to the effects of digitalization process on labour market; more evidence is still needed to examine the impact of digitalization innovations on job creation, employment/unemployment level, required skills changing.

The problem of reducing labour productivity needs special attention and can be the content of further investigation. Also, special attention should be paid to the questions of digitalization policies and regularities of different European countries and their role in creating digital gaps.

Table 4 - Results of research hypotheses testing

\begin{tabular}{|l|l|}
\hline Research hypothesis & Proved / rejected \\
\hline $\begin{array}{l}\text { H1: there is a significant gap within EU- } \\
\text { members in digital development and labour } \\
\text { productivity }\end{array}$ & $\begin{array}{l}\text { Proved. Results of cluster analysis show difference in intensity if } \\
\text { digitalization processes and level of labour productivity among } \\
\text { EU-members }\end{array}$ \\
\hline $\begin{array}{l}\text { H2: digital development of EU-members can } \\
\text { improve country's global rankings: Global } \\
\begin{array}{l}\text { Competitiveness Score, Information } \\
\text { development Index, Human development } \\
\text { index }\end{array}\end{array}$ & $\begin{array}{l}\text { Partially Proved. By DESI International and Global } \\
\text { for EU members and 8 developed countries. Members of leading } \\
\text { cluster has higher positions in IDI and HDI Rankings, that } \\
\text { countries of transition cluster, but further investigations in this } \\
\text { area still need }\end{array}$ \\
\hline
\end{tabular}

\section{Conclusions}

The studies carried out prove that there are gaps in the digitalization process among EU members. Cluster analysis helped to form four clusters: in the first case, based on the digitalization index and labor productivity, in the second case - taking into account the global competitiveness score. There is a group of Northern European countries leading in the digitalization process, while a number of Eastern and Central European countries are at the bottom of this ranking. So, Results of cluster analysis show difference in intensity if digitalization processes and level of labour productivity among EU-members. Digital development of EU-members can improve country's global rankings - all members of leading cluster save their positions in global competitiveness score clusterization. The same is true for transiting cluster: the members of this cluster are the same for two cluster analysis. 
Results of cluster analysis show the linkage between digital development and human development due to co-movement of DESI and Human Development Index. Members of leading cluster has higher positions in IDI and HDI Rankings, that countries of transiting cluster. But digital development is only one of the many factors that determine information sector and human development. That is why the co-movement of such ranking needs further investigations.

For further investigations one can analyze digital policies of EU-members and their effects on economic and digital performance of the country, also it will be useful to continue research in a field of digital impact on labour market.

\section{References}

Abonyi, J., \& Feil, B. (2007). Cluster Analysis for Data Mining and System. Birkhauser Verlag AG.

Amuso, V., Poletti, G., \& Montibello, D. (2019). The Digital Economy: Opportunities and Challenges. Global Policy, 11(1), 124-127. https://doi.org/10.1111/1758-5899.12745

Androniceanu, A., Georgescu, I., \& Kinnunen, J. (2019). Digitalization Clusters within the European Union. In IBIMA, 33rd IBIMA Conference, Granada, Spain 10-11 April, 2019 (pp. 1321-1331).

Antonelli, C. (2003). The digital divide: understanding the economics of new information and communication technology in the global economy. Information Economics and Policy, 15(2), 173-199. https://doi.org/10.1016/S0167-6245(02)00093-8

Ark Van, B., Inklaar, R., McGuckin, R. H., \& Timmer, M. P. (2003). The Employment Effects of the "New Economy": A Comparison of the European Union and the United States (EPWP \#03-02). Economics Program Working Paper Series. University of Groningen and The Conference Board.

Balcerzak, P. A., \& Pietrzak, B. M. (2017). Digital Economy in Visegrad Countries. Multiple-criteria Decision Analysis at Regional Level in The Years 2012 and 2015. Journal of Competitiveness, 9(2), 5-18. https://doi.org/10.7441/joc.2017.02.01

Bilozubenko, V., Yatchuk, O., Wolanin, E., Serediuk, T., \& Korneyev, M. (2020). Comparison of the digital economy development parameters in the EU countries in the context of bridging the digital divide. Problems and Perspectives in Management, 18(2), 206-218. https://doi.org/10.21511/ppm.18(2).2020.18

Biagi, F. (2013). ICT and Productivity: A Review of the Literature (JRC Working Papers on Digital Economy 201309). Joint Research Centre. https://doi.org/10.2788/32940

Chakravorti, B., \& Chaturvedi, R. S. (2017). Digital planet 2017: How competitiveness and trust in digital economies vary across the world.

Chen, W., \& Wellman, B. (2004). The Global Digital Divide - Within and Between Countries. IT E Society, 1(7), 39-45. http://citeseerx.ist.psu.edu/viewdoc/summary?doi=10.1.1.207.1713

Chipeva, P., Cruz-Jesus, F., Oliveira, T., \& Irani, Z. (2018). Digital divide at individual level: Evidence for Eastern and Western European countries. Government Information Quarterly, 35(3), 460-479. https://doi.org/10.1016/j.giq.2018.06.003

Digital Economy and Society Index (DESI). (2020). https://ec.europa.eu/digital-single-market/en/digitaleconomy-and-society-index-desi.

European Commission. (2015). A Digital Single Market Strategy for Europe (A Communication Paper SWD (2015) 192). European Union.

Foster, C., \& Azmeh, S. (2020). Latecomer Economies and National Digital Policy: An Industrial Policy Perspective. The Journal of Development Studies, 56(7), 1247-1262. https://doi.org/10.1080/00220388.2019.1677886

ITU. (n.d.). The ICT Development Index (IDI): Methodology, indicators and definitions. International Telecommunication Union. https://www.itu.int/en/ITUD/Statistics/Documents/statistics/ITU_ICT\%20Development\%20Index.pdf

European Commission. (2021). The Digital Economy and Society Index (DESI). https:/ec.europa.eu/digital-singlemarket/en/digital-economy-and-society-index-desi 
Kinnunen, J., Androniceanu, A., \& Georgescu, I. (2019). Digitalization of EU Countries: a Clusterwise Analysis. In The 13th International management conference "Management Strategies for High Performance" 31st October1st November, 2019, Bucharest, Romania.

Lucendo-Monedero, A. L., Ruiz-Rodriguez, F., \& Gonzalez-Relano, R. (2019). Measuring the digital divide at regional level. A spatial analysis of the inequalities in digital development of households and individuals in Europe. Telematics and Informatics, 41, 197-217. https://doi.org/10.1016/j.tele.2019.05.002hr/213607

Mardikyan, S., Aycicek, E., Mehmet, Y., Ordu, D., \& Şimşek, B. (2015), Examining the Global Digital Divide: A Cross-Country Analysis. Communications of the IBIMA (Vol. 2015). Article ID 592253. https://doi.org/10.5171/2015.592253

Milošević, N., Dobrota, M., \& Barjaktarovic Rakocevic, S. (2018). Digital economy in Europe: Evaluation of countries' performances. Zbornik Radova Ekonomskog Fakultet au Rijeci, 36(2), 861-880. https://doi.org/10.18045/zbefri.2018.2.861

Nambisan, S., Wright, M., \& Feldman, M. (2019). The digital transformation of innovation and entrepreneurship: Progress, challenges and key themes. Research Policy, 48(8), 1-9. https://doi.org/10.1016/j.respol.2019.03.018

Novak, J., Purta M., Marciniak, M., Ignatowicz, K., Rozenbaum, K., \& Yearwood, K. (2018). The rise of Digital Challengers - How digitization can become the next growth engine for Central and Eastern Europe. Digital McKinsey. McKinsey \& Company.

OECD. (2016). Stimulating digital innovation for growth and inclusiveness: The role of policies for the successful diffusion of ICT (OECD Digital Economy Papers, No. 256). OECD Publishing, Paris. https://doi.org/10.1787/5jlwqvhg3131-en

Polozova, T. V. (2015). Formation of feature space for diagnostics of innovative investment capability of an enterprise. Actual Problems of Economics, 170(8), 450-460.

Terziyan, V., Gryshko, S., \& Golovianko, M. (2018). Patented intelligence: Cloning human decision models for Industry 4.0. Journal of Manufacturing Systems, 48, 204-217. https://doi.org/10.1016/j.jmsy.2018.04.019

United Nations Development Programme (UND). (2018). 2018 Statistical Update: Human Development Indices and Indicators. http://hdr.undp.org/en/content/human-development-indices-indicators-2018

WEF. (2018). The Global Competitiveness Report. World Economic Forum. https://www.weforumorgreportstheglobalcompetitvenessreport 